九州大学学術情報リポジトリ

Kyushu University Institutional Repository

\title{
Variation of Dissolved Oxygen in the Flooding Water of the Paddy Fields
}

Phuc, Nguyen

Laboratory of Irrigation Engineering, Faculty of Agriculture, Kyushu University

Tanabe, Kunimi

Laboratory of Irrigation Engineering, Faculty of Agriculture, Kyushu University

Kuroda, Masaharu

Laboratory of Irrigation Engineering, Faculty of Agriculture, Kyushu University

https://doi.org/10.5109/22887

出版情報：九州大学大学院農学研究院紀要. 20 (1)，pp.47-60，1975-10. Kyushu University バージョン：

権利関係 : 


\title{
Variation of Dissolved Oxygen in the Flooding Water of the Paddy Fields
}

\section{Nguyen Phuc, Kunimi Tanabe and Masaharu Kuroda}

\author{
Laboratory of Irrigation Engineering, Faculty of \\ Agriculture, Kyushu University, Fukuoka
}

(Received August 8, 1975)

\begin{abstract}
The experimental measurements were carried out of DO (dissolved oxygen) in the flooding water of lysimeters, paddy fields and creeks during the rice planting seasons in 1973 and 1974. The DO diurnal curves were obtained under various conditions of the water bodies. Accordingly, the DO variation in the flooding water of the paddy fields is mostly attributable to the source and sink due to the metabolic activities of aquatic organisms in the water.

It is noted that in the day time, the DO increases with the intensity of diurnal solar radiation and the maximum values of DO can attain more than 200 percent to the saturation index. On the other hand, after sun set, the DO steeply falls toward the values about 50 percent or less to the saturation index.

The DO change rate $f(t)$ and its components $p(t), h(t)$ and $e(t)$ can be evaluated, where $p(t)$ is the DO production rate, $h(t)$ is the DO consumption rate and $e(t)$ is the $\mathrm{DO}-\mathrm{O}_{2}$ exchange rate between atmosphere and water. As understanding these factors, it is possible to recognize that $p(t)$ is dependent on the photosynthetic activity of green algae and $\mathrm{h}(\mathrm{t})$ is ascribable to the chemical and biological absorptions.

It is clear to obtain that the daily DO production $P$ and daily DO consumption $H$ increase under the condition of large density of green algae at raised intensity of solar radiation, whereas both $P$ and $H$ decrease provided that small density of green algae in the flooding water of paddy fields.
\end{abstract}

\section{INTRODUCTION}

Among the natural substances existing under either gaseous or liquid phase, oxygen is a characteristic one that appears frequently as a solute and plays the physical, chemical and biological roles in the water.

Many previous authors have studied the roles of dissolved oxygen (DO) under the various points of view. Truesdale et al. (1955), Montgomery et al. (1964) and Carpenter (1966) measured the solubility of oxygen in the water. Downing and Truesdale (1955), Kanwisher (1963) and Liss (1973) speculated on the exchange of oxygen between atmosphere and water body. Ryther (1956) and Bartsch (1961) observed the species of algae as a source of oxygen in the water. Odum (1956) and Welch (1968) discussed the variations of dissolved oxygen in flowing water and standing water. In addition, Darby (1962) and Toyota (1972) attempted to mention the correlation among the factors such as $\mathrm{DO}, \mathrm{pH}$, alkalinity, EC, temperature and so on in the flooding water of paddy fields and in the water used to irrigate the paddy fields. 
This study aims at performing the observations and experimental measurements of DO variations under various environmental conditions of the flooding water in the paddy fields by using the DO meters. These works were carried out in the lysimeters located inside the campus of Kyushu University and in the actual paddy fields situated in Saga plain in the rice planting seasons of 1973 and 1974.

\section{THEORETICAL CONSIDERATION ON DIURNAL VARIATION OF 'DO' IN WATER}

The function $\mathrm{F}(\mathrm{t})$ is defined as the value of DO at time $t$. The DO change rate $f(t)$ can be converted from the relation:

$$
f(t)=\frac{d F(t)}{d t}
$$

The function $f(t)$ can be assumed consisting of such components as production rate $p(t)$, consumption rate $h(t)$ and exchange rate $\mathrm{e}(\mathrm{t})$ :

$$
f(t)=p(t)-h(t)+e(t)
$$

(a) Evaluation of $p(t), h(t)$ and $e(t)$

The method to evaluate $\mathbf{f}(\mathbf{t})$ and its components $p(t), h(t)$ and $e(t)$ is indicated in Fig. 1. The uppermost part (A) shows the DO diurnal curve $F(t)$ and saturated DO curve $\mathrm{G}(\mathrm{t})$.

Curve $\mathbf{f ( t )}$ in part (B) is drawn by plotting the differences between the DO values measured every one hour and part (C) is related to the so called reaeration coefficient $K$ that is proportional to the exchange rate $e(t)$ in the equation:

$$
e(t)=K S
$$

Where, $\mathrm{S}$ is the oxygen saturation deficit and equals $G(t)-F(t)$.

If presuming the consumption rate $\mathrm{h}(\mathrm{t})$ is invariable, plotting the change rate at night (no photosynthesis) against the saturation deficit $\mathrm{S}$ should give the line whose slope is equal to $K$. From the known value of $K, e(r)$ can be calculated from Eq. (3).

To obtain the consumption rate $\mathrm{h}(\mathrm{t})$, the known exchange rate $e(t)$ is subtracted from the curve $\mathbf{f}(\mathbf{t})$ during the darkness. The DO production rate $p(t)$ is obtained finally by separating the DO exchange rate $e(t)$ and consumption rate $h(t)$ from the DO change rate $f(t)$ as indicated in part (D).

(b) Accumulation of $\mathbf{p}(\mathbf{t}), \mathbf{h}(\mathbf{t})$ and $\mathbf{e}(\mathbf{t})$

The accumulation of the components $\mathrm{p}(\mathrm{t}), h(t)$ and $\mathrm{e}(\mathrm{t})$ can be calculated in $\mathrm{ppm} /$ day by reckoning the area under each individual involved curve:

$$
\begin{aligned}
P & =\int_{0}^{24} p(t) d t \\
H & =\int_{0}^{24} h(t) d t \\
E & =\int_{0}^{24} e(t) d t
\end{aligned}
$$

Multiplying Eq. (4) with the water depth $z$ (meter), the expressions are converted in $\mathrm{g} / \mathrm{m}^{2} /$ day. 
In many natural water bodies, a maximum in the afternoon and a minimum just before dawn of DO are observed and indicated as in part (A) of Fig. 1. The saturated DO tends to fall slightly in the afternoon due to the raise of temperature.
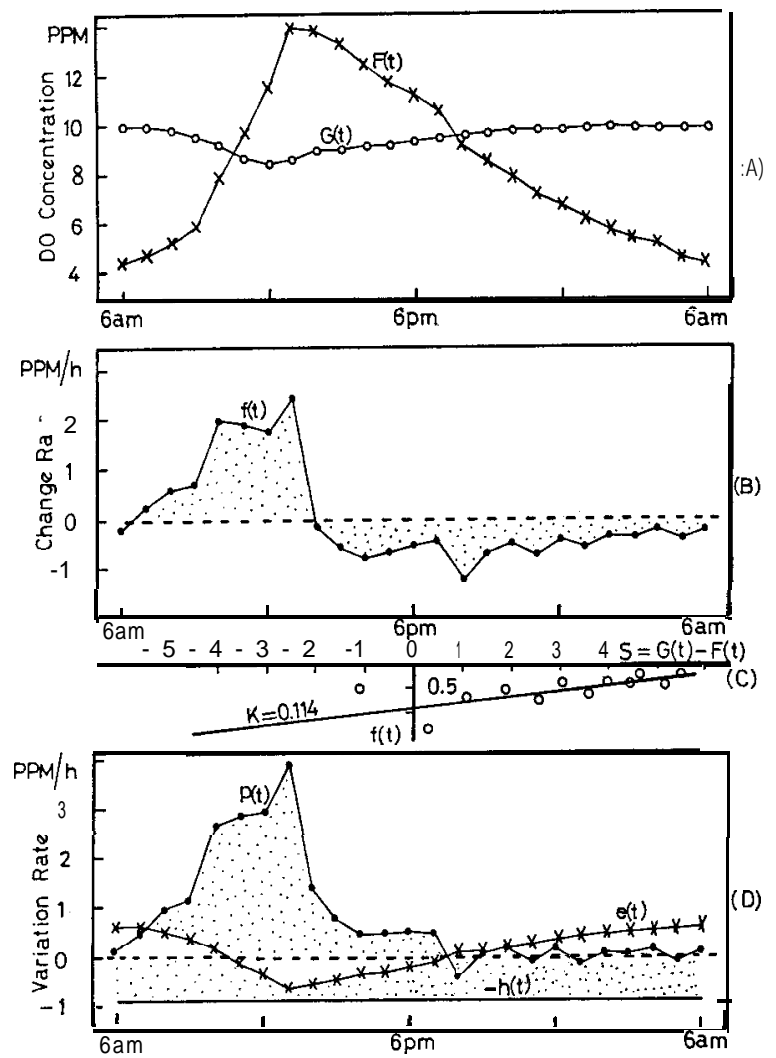

Fig. 1. Evaluation of values $p(t), h(t)$ and $\mathrm{e}(\mathrm{f})$.

\section{MATERIALS AND METHODS}

In the rice planting season of 1973 , the experimental works were performed in the lysimeter and pots while in the season of 1974, they were done in the lysimeters and actual paddy fields.

(a) The case of rice planting season in 1973

As illustrated in Fig. 2, the concentrations of dissolved oxygen in water were measured in the lysimeter and in pots transplanted with rice plants on July 1 and in the 3 tanks contained water with separated living aquatic organism, for example, $T_{1}$ with water only, $T_{2}$ with water and duck-weeds and $T_{3}$ with water and green algae.

The flooding water in the transplanted parts of the lysimeter was allowed 
to percolate into each separate part $\mathrm{Cr}, \mathrm{Cr}$, and $\mathrm{Cr}$, of the creek which was attached with the concrete block of the lysimeter. The depth of water was kept $10 \mathrm{~cm}, 90 \mathrm{~cm}, 5 \mathrm{~cm}$ and $17 \mathrm{~cm}$ in the transplanted parts of lysimeter, creek, pots and tanks, respectively.

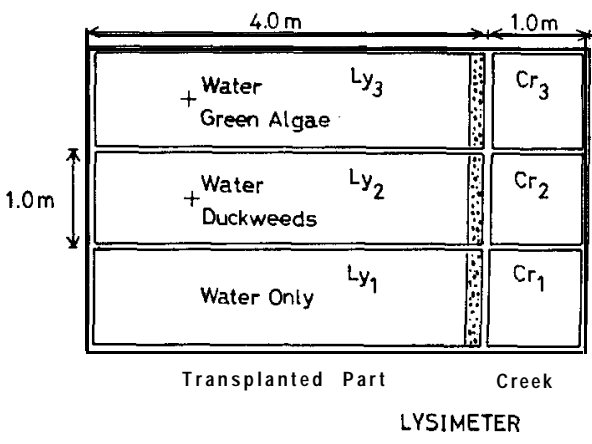

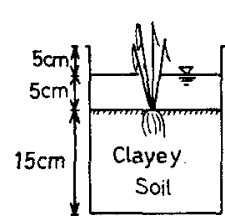

Pot .1

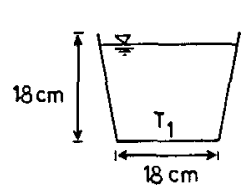

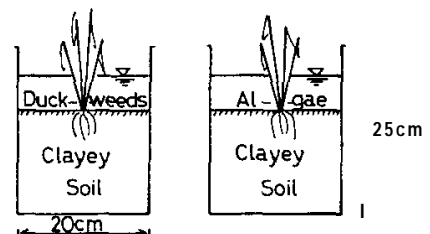

Pot.3

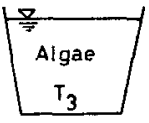

Fig. 2. Schematic diagram of experimental measurements in the season of 1973.

(b) The case of rice planting season in $\mathbf{1 9 7 4}$

The diagrams of experimental measurements in the season of 1974 are demonstrated in Fig. 3 for the lysimeters and Fig. 4 for the actual paddy fields.

In the rice planting season in 1974, the lysimeters were transplanted with rice plants: $\mathrm{BLOC}(\mathrm{l})$ and $\mathrm{BLOC}(3)$ were located in the campus of Faculty of Agriculture, Kyushu University, and while the actual paddy fields were situated at Mikazuki and Saga Agricultural Experimental Station (E. Station) in Saga Plain : BLOC(4) and BLOC(5).

\section{(c) Method of measurement}

The DO meters used for the measurements were Model 715 Process Oxygen Monitor in the season of 1973 and Fieldlab Oxygen Analyser in the season of 1974. Moreover, the other factors such as temperature, solar radiation, rate of rice growth and the general circumstances of the experimental places were also observed and measured. 


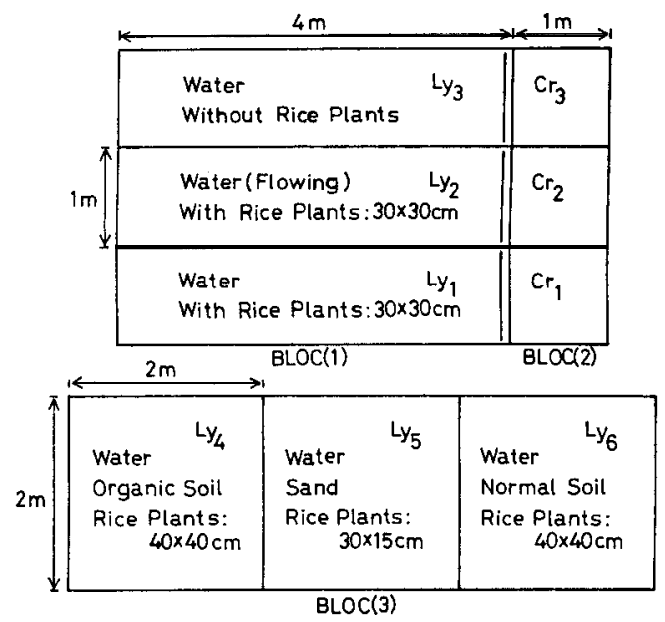

Fig. 3. Experimental conditions in lysimeters.
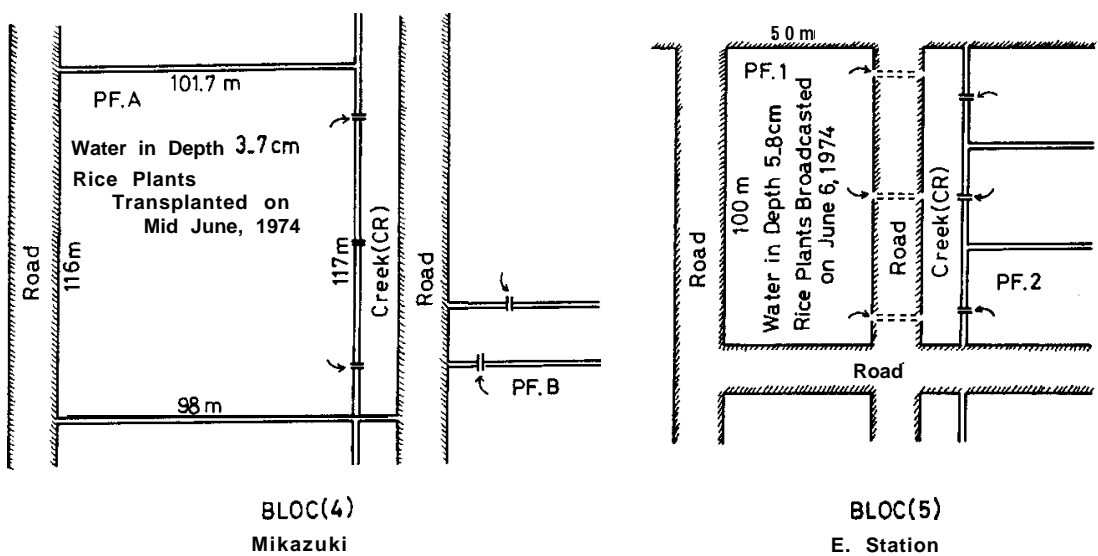

Fig. 4. Experimental conditions in paddy fields.

\section{RESULTS AND DISCUSSION}

(a) Results of rice planting season in $\mathbf{1 9 7 3}$

In Fig. 5, part (A) indicates the daily variation of DO in the lysimeter consisting of the transplanted parts $\mathrm{Ly}, \mathrm{Ly}_{2}, \mathrm{Ly}_{3}$, part (B), those of the creek $\mathrm{Cr}, \mathrm{Cr}, \mathrm{Cr}$, and part(C), those of the tanks $\mathrm{T}_{1}, \mathrm{~T}_{2}, \mathrm{~T}$,

The DO variation was largest in Ly, and $\mathrm{T}_{3}$ availing green alga Pithophora as a result of photosynthesis in the day time and respiration at night. In $\mathrm{Ly}_{2}$ and $\mathrm{T}_{2}$ with duckweed Spirodela, there was nearly no variation, because the photosynthetic effect was limited at the water surface where the leaves of Spirodela were floating.

Ly, with unknown green algae other than Pithophora indicated such DO to be greater in day-time and smaller at night while $T_{1}$ with only tap water did 
not show any change in DO.

A little raise of $\mathrm{DO}$ in $\mathrm{T}_{2}$ with duckweed Spirodela might be due to the photosynthetic activity of unknown green algae coexisting with Spirodela.

In the water of creek, the $\mathrm{DO}$ values were usually in the undersaturated condition. It was likely that the DO in creek water depended on the percolation rate of water leaking from the transplanted parts of the lysimeter, but the percolating water was frequently influenced by the communities of green algae growing in water or attaching on the creek walls..

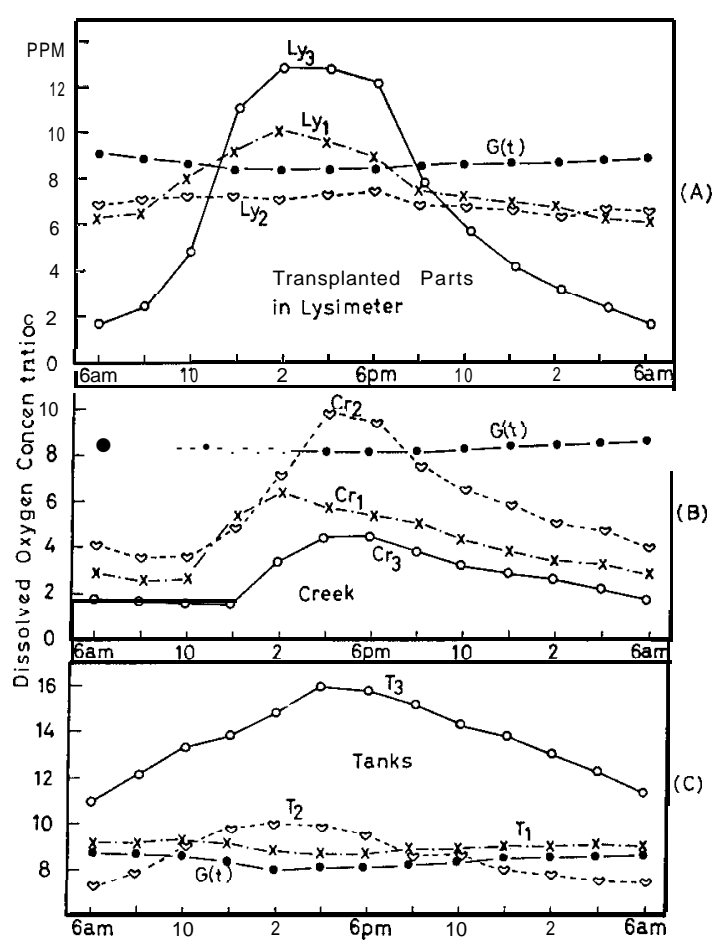

Fig. 5. DO diurnal curves measured in the parts of lysimeter, creek and tanks on Sept. 5-6, 1973.

Fig. 6 shows the development of rice plants in length (plant height) and width (tiller number) in the lysimeter under different stages of the growth. After the tillering stage, the tiller number did not change so much while the plant height continued to elongate until the flowering stage.

In Fig. 7, the DO diurnal curves in flooding water of pots transplanted with rice plants are demonstrated, The DO deviation was shown to be highest in Pot. 3 with water containing green algae and lowest in Pot. 2 with water containing duckweeds. In Pot. 1, the DO curve rose a little in the day time as a result of photosynthesis of unknown green algae. 


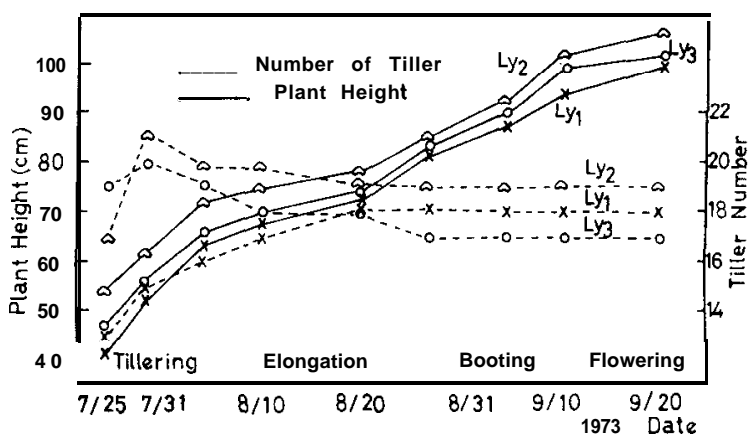

Fig. 6. Growth in height and tiller number of rice plants in the lysimeter
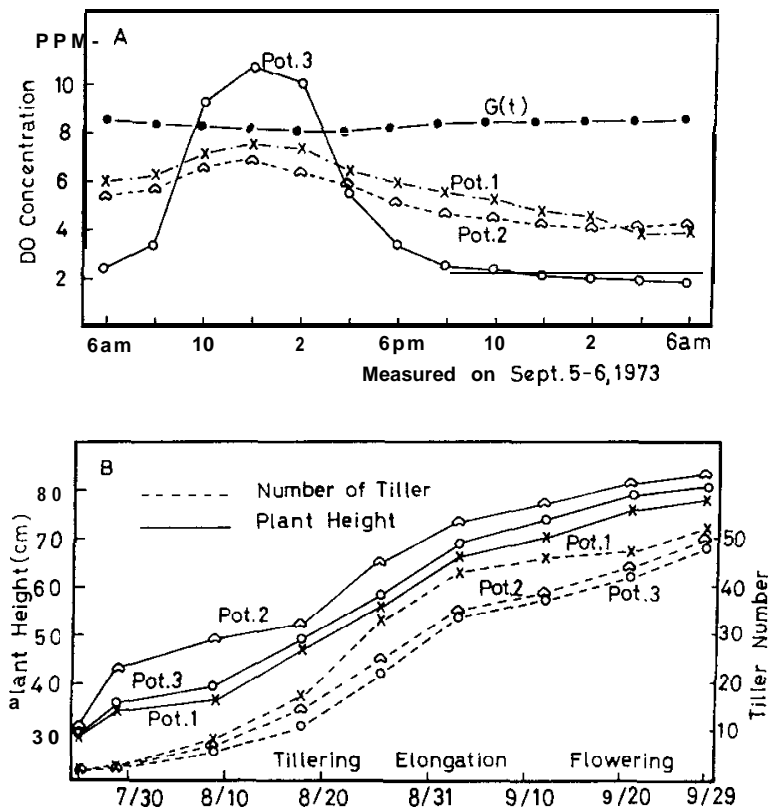

Fig. 7. A: DO diurnal curves of flooding water in pots. B: Growth in height and tiller number of rice plants in pots.

\section{(b) Results of rice planting season in 1974}

Results of measurements on many days in the lysimeters are demonstrated in Fig. 8.

$\operatorname{BLOC}(\mathrm{Z})$ : $\mathrm{Ly}_{1}$ had the largest deviation of DO on August 13, when both temperature and intensity of solar radiation were notified in the largest values. The DO deviation in Ly, was the lowest as a direct result of flowing action of water in this place. On July 19, the water in Ly, was muddy condition, thus very small values of DO were resulted. When the water in Ly, became much clearer (Aug. 13 and Sept. 5), green algae and higher plants developed more actively and very great DO values were obtained. 


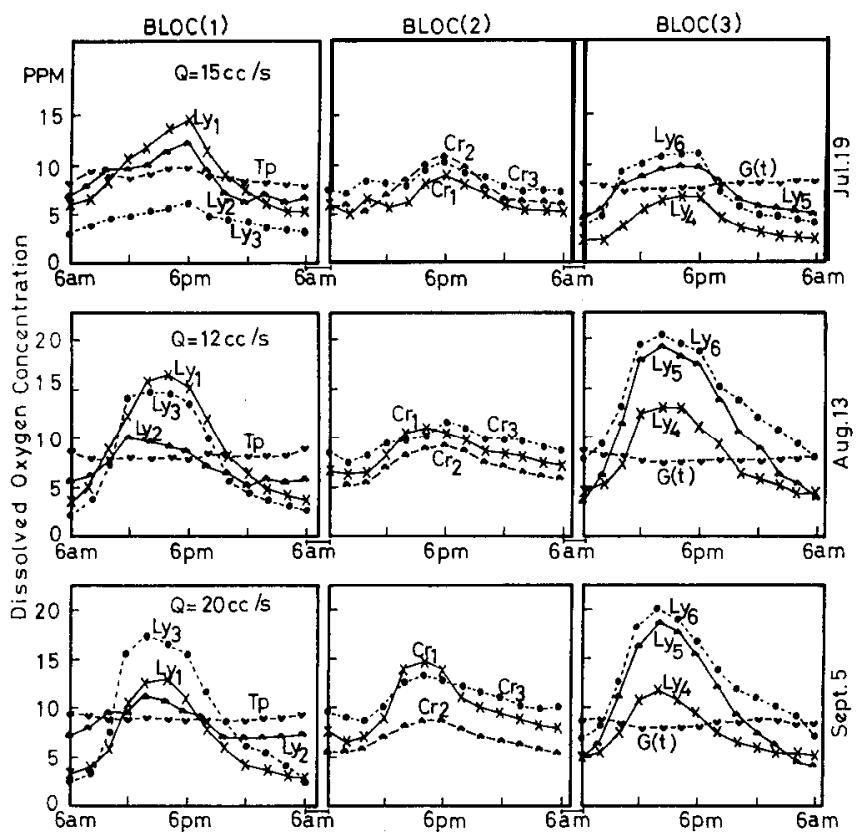

Fig. 8. DO diurnal curves measured on different days in the rice planting season of 1974.

The smaller DO values in Ly, than in Ly, on Aug. 13 and the greater DO values in Ly, than in Ly, on Sept. 5 could be explained by the fact that the rice plants in Ly, had grown up in this period and their shadows might interrupt the solar radiation to reach onto the water. This reduced the photosynthetic activities of green algae in water and resulted in lower DO values. On the contrary, Ly, was not planted with rice plants but the green algae thrived well in water during the same period, so the sun-light should accelerate the assimilation of carbon dioxide due to green algae and result in the larger DO production. The curves $T_{p}$ indicate the $D O$ variation of tap water supplied to $\mathrm{Ly}$, , and the letter $\mathrm{Q}$ presents the overflow rate from $\mathrm{Ly}$, into $\mathrm{Cr}$,.

$B L O C(2)$ : This consists of 3 parts: $\mathrm{Cr}, \mathrm{Cr}$, and $\mathrm{Cr}$. . The $\mathrm{DO}$ values were nearly the same in $\mathrm{Cr}$, and $\mathrm{Cr}$, due to the similar stagnant condition of water in these 2 places. The variation of DO in water of $\mathrm{Cr}$, seemed to depend on the overflow rate $\mathrm{Q}$. As time elapsed, the dense community of green algae affected increasingly the DO in this place.

$B L O C(3)$ : In Ly, the lowest values of DO were obtained in the condition of absence of Pithophora during the first half of the rice planting season. This might be due to the organic materials in the soil. It is well known that the organic matters in soil have the ability to absorb oxygen in water. As in Ly, Pithophora thrived and spread fully in the water body, the values of DO were slightly greater than those in $\mathrm{Ly}_{\tilde{\sigma}}$ wherever the less community of Pithophora was observed.

Results of measurement in the paddy fields are indicated in Fig. 9 with 
BLOC(4) for those in Mikazuki and BLOC(5) for those in E. Station.

$B L O C(I)$ : In the paddy fields at Mikazuki, Pithophora did not thrive so well and the paddy soil was common to those in many other paddy fields. These brought about less variations of $\mathrm{DO}$ as seen in PF. A and PF. B. A large deviation of DO in the creek water of Mikazuki revealed the abundance of various species of green algae. On Sept. 2425, the DO depleted less than those on Jul. 22-23 and Aug. 21-22, because of the inevitable decrease of solar radiation intensity and the consequent temperature decrease.

$B L O C(S)$ : In the paddy fields at E. Station, Pithophora developed abundantly in the flooding water. Particularly in PF. 1, the organic matter decomposed from the barley stubbles of the previous planting season was observed in large amount. These resulted in very large value of DO in the day time due to the intensive photosynthesis and small value of DO at night due to both decomposition of organic detritus and the biological respiration.

Except the data on Sept. 25 26, the DO values of day time in the water bodies of PF. 1, PF. 2 and CR were oversaturated due to high degrees of temperature and intensity of solar radiation. The variation of $\mathrm{DO}$ in the creek water (CR) was observed to be in similar way of that in the creek water at Mikazuki.

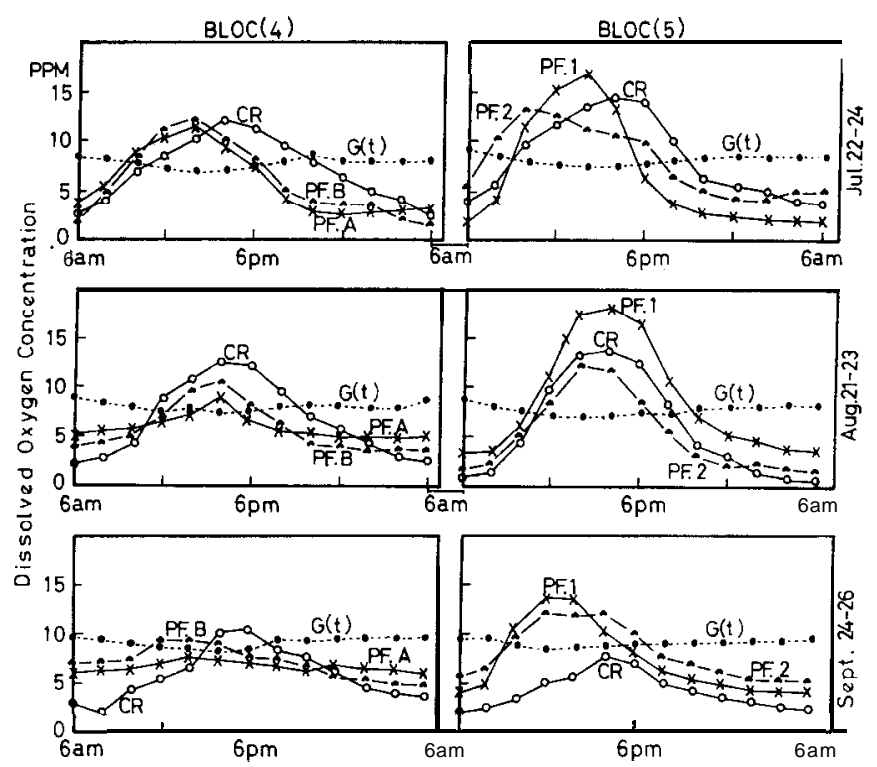

Fig. 9. DO diurnal curves measured on different days in the rice planting season of 1974.

(c) Accumulation values of $\mathbf{h}(\mathbf{t})$, $\mathbf{e}(\mathbf{t})$ and $\mathbf{p}(\mathbf{t})$

The daily DO consumption $H$, exchange $E$ and production $P$ are defined as the integrated forms of the DO consumption rate $h(t)$, exchange rate $e(t)$ and production rate $p(t)$, respectively.

The following results were obtained from the measurements of DO in the 
flooding water bodies at the lysimeters and paddy fields. The hourly maximum (Max.), average (Ave.) and minimum (Min.) DO values in the days of experiment were also given.

Table 1. Daily DO consumption $(H)$, daily $\mathrm{DO}-\mathrm{O}_{2}$ exchange $(\mathrm{E})$ and daily DO production $(\mathrm{P})$ with their hourly maximum, average and minimum values obtained from BLOC (1).

\begin{tabular}{|c|c|c|c|c|c|c|c|c|c|c|}
\hline \multirow{2}{*}{ D a te } & \multicolumn{3}{|c|}{$\mathrm{Ly}_{1}$} & & \multicolumn{3}{|c|}{$\mathrm{Ly}_{2}$} & \multicolumn{3}{|c|}{$\mathrm{Ly}_{3}$} \\
\hline & $H$ & $E$ & $P$ & & $H$ & $E$ & $P$ & $H$ & $E$ & $P$ \\
\hline $\begin{array}{l}7 / 19 \\
8 / 02 \\
8 / 13\end{array}$ & $\begin{array}{l}21.3 \\
19.0\end{array}$ & $\begin{array}{l}-3.6 \\
-0.4\end{array}$ & $\begin{array}{l}23.4 \\
19.2\end{array}$ & & $\begin{array}{l}12.2 \\
22.8 \\
18.2\end{array}$ & $\begin{array}{l}-9.5 \\
-8.0 \\
+3.3\end{array}$ & $\begin{array}{l}21.6 \\
30.6 \\
14.7\end{array}$ & $\begin{array}{r}18.5 \\
35: 24.00\end{array}$ & $\begin{array}{l}+10.8 \\
+.64 .9\end{array}$ & $\begin{array}{l}3010.1 \\
33.229 .0\end{array}$ \\
\hline $\begin{array}{l}9 / 05 \\
9 / 19\end{array}$ & $\begin{array}{l}26.428 .7 \\
20.5\end{array}$ & $\begin{array}{r}+4.6-3.9 \\
+ \\
+ \\
\end{array}$ & $\begin{array}{l}30.224 .4 \\
17.6\end{array}$ & & $\begin{array}{l}10.8 \\
18.3\end{array}$ & $\begin{array}{r}-3.1 \\
+3.7\end{array}$ & $\begin{array}{l}14.3 \\
15.4\end{array}$ & $\begin{array}{l}31.3 \\
18.0\end{array}$ & $\begin{array}{l}-6.2 \\
-8.6\end{array}$ & $\begin{array}{l}37.3 \\
28.6\end{array}$ \\
\hline $10 / 05$ & 21.0 & $\begin{array}{r}4.4 \\
+2.7\end{array}$ & 19.3 & & 15.3 & $\begin{array}{r}10.1 \\
+4.2\end{array}$ & $\begin{array}{l}10.4 \\
11.5\end{array}$ & $\begin{array}{l}10.0 \\
15.4\end{array}$ & $\begin{array}{l}-8.0 \\
-7.4\end{array}$ & $\begin{array}{l}20.0 \\
22.6\end{array}$ \\
\hline Average & 22.8 & $\div 0.6$ & 22.3 & & 16.2 & -1.6 & 18.0 & 23.7 & -- 2.8 & 26.8 \\
\hline \multirow{2}{*}{ Date } & \multicolumn{3}{|c|}{$\mathrm{Ly}_{1}$} & & \multicolumn{3}{|c|}{$\mathrm{Ly}_{2}$} & \multicolumn{3}{|c|}{$\mathrm{Ly}_{3}$} \\
\hline & Max. & Ave. & Min. & ! & Max. & Ave. & Min. & Max. & Ave. & Min. \\
\hline $\begin{array}{r}7 / 19 \\
8 / 02 \\
8 / 13 \\
9 / 05 \\
9 / 19 \\
10 / 05\end{array}$ & $\begin{array}{l}16.0 \\
12.3 \\
14.0\end{array}$ & $\begin{array}{l}9.3 \\
8.2 \\
9.8 \\
8.8 \\
9.0 \\
8.8\end{array}$ & $\begin{array}{l}5.2 \\
4.2 \\
3.0 \\
3.9 \\
5.0 \\
4.5\end{array}$ & & $\begin{array}{l}10.3 \\
11.3 \\
11.0\end{array}$ & $\begin{array}{l}9.6 \\
9.5 \\
7.5 \\
8.9 \\
9.1 \\
8.9\end{array}$ & $\begin{array}{l}6.5 \\
5.4 \\
5.7 \\
6.3 \\
6.5 \\
6.3\end{array}$ & $\begin{array}{r}.200 .6 .4 \\
15.616 .3\end{array}$ & $\begin{array}{r}4.2 \\
8.9 \\
7.7 \\
9.4 \\
11.3\end{array}$ & $\begin{array}{l}3.2 \\
4.2 \\
2.5 \\
3.0 \\
5.0 \\
6.3\end{array}$ \\
\hline Average & 14.0 & 9.0 & 4.3 & & 12.1 & 8.9 & 6.1 & 15.8 & 8.9 & 4.0 \\
\hline
\end{tabular}

A review of Table $1,2,3$ and 4 brings the next interpretations:

(1) The greater the DO Max. in water with abundant green algae, the smaller the DO Min. is accompanied. This can be interpreted with both large values of daily DO consumption $\mathbf{H}$ and production $\mathbf{P}$ such as the cases of Ly, in BLOC(1), Ly, and Ly, in BLOC(S), CR in BLOC(4), PF. 1 and PF. 2 in BLOC (5).

(2) When the daily DO consumption $\mathbf{H}$ and production $\mathbf{P}$ are nearly equal, the $\mathrm{DO}-\mathrm{O}_{2}$ exchange $E$ is very small, as exemplified with those in Ly, of BLOC (1), PF. 2 of BLOC(5). The positive or negative values of the daily DO-O, exchange $\mathbf{E}$ depends on the relation of either $\boldsymbol{P}>\boldsymbol{H}$ or $\mathbf{P}<\mathbf{H}$.

(3) In the paddy field with high content of organic materials in soil and low density of algal community in flooding water, DO was low due to the large value of daily consumption $\mathbf{H}$ and small value of daily production $\mathbf{P}$ as in the case of Ly, in BLOC(3).

(4) In the paddy field with high content of organic material in soil and dense algal community in water, both daily consumption $\mathbf{H}$ and production $\mathbf{P}$ were found to be very large: PF. 1 and PF. 2 of BLOC(5).

(5) In the paddy field with low content of organic matter in soil and thin algal community in water, both values of $\mathbf{H}$ and $\mathbf{P}$ were found to be small as in PF. A and PF. B of BLOC(4). 
Table 2. Daily DO consumption $(\mathrm{H})$, daily $\mathrm{DO}-\mathrm{O}_{2}$ exchange $(\mathrm{E})$ and daily DO production $(\mathrm{P})$ with their hourly maximum, average and minimum values obtained from BLOC (3).

\begin{tabular}{|c|c|c|c|c|c|c|c|c|c|}
\hline \multirow{2}{*}{ D a } & \multirow{2}{*}{${ }^{\mathrm{t}} H$} & \multirow{2}{*}{$\frac{\mathrm{Ly}_{4}}{E}$} & \multirow[b]{2}{*}{$P$} & \multirow[b]{2}{*}{$H$} & \multicolumn{2}{|l|}{$\mathrm{Ly}_{5}$} & \multicolumn{3}{|c|}{$\mathrm{Ly}_{6}$} \\
\hline & & & & & $E$ & $P$ & $H$ & $E$ & $P$ \\
\hline $\begin{array}{r}7 / 19 \\
8 / 02 \\
8 / 13 \\
9 / 05 \\
9 / 19 \\
10 / 05\end{array}$ & $\begin{array}{l}21.4 \\
15.8 \\
13.8 \\
17.6 \\
13.0 \\
15.1\end{array}$ & $\begin{array}{r}+10.8 \\
+2.4 \\
+2.4 \\
+2.3 \\
+\quad 0.1 \\
+3.6\end{array}$ & $\begin{array}{l}10.4 \\
12.9 \\
20.2 \\
15.3 \\
14.2 \\
11.5\end{array}$ & $\begin{array}{l}13.5 \\
23.8 \\
25.0 \\
24.8 \\
17.2 \\
14.0\end{array}$ & $\begin{array}{l}+1.20 \\
-9.40 \\
-6.30 \\
-7.20 \\
-5.90 \\
-2.10\end{array}$ & $\begin{array}{l}13.6 \\
33.1 \\
31.8 \\
31.6 \\
24.3 \\
16.6\end{array}$ & $\begin{array}{l}19.1 \\
23.6 \\
10.8 \\
10.3 \\
14.6 \\
16.4\end{array}$ & $\begin{array}{r}+2.0 \\
-14.2 \\
-12.8 \\
-10.5 \\
-6.1 \\
-\quad 2.3\end{array}$ & $\begin{array}{l}17.0 \\
37.5 \\
24.2 \\
21.2 \\
23.0 \\
18.3\end{array}$ \\
\hline Average & 16.9 & +2.8 & 14.1 & 19.7 & --4.90 & 25.2 & 15.8 & -7.3 & 23.5 \\
\hline \multirow{2}{*}{ Date } & \multicolumn{3}{|c|}{$\mathrm{Ly}_{4}$} & \multicolumn{3}{|c|}{$\mathrm{Ly}_{5}$} & \multicolumn{3}{|c|}{$\mathrm{Ly}_{6}$} \\
\hline & Max. & Ave. & Min. & Max. & Ave. & Min. & Max. & Ave. & Min. \\
\hline $\begin{array}{r}7 / 19 \\
8 / 02 \\
8 / 13 \\
9 / 05 \\
9 / 19 \\
10 / 05\end{array}$ & $\begin{array}{r}7.2 \\
11.0 \\
13.9 \\
11.0 \\
13.8 \\
11.5\end{array}$ & $\begin{array}{l}4.7 \\
7.4 \\
8.7 \\
7.2 \\
9.9 \\
8.4\end{array}$ & $\begin{array}{l}2.6 \\
4.8 \\
4.5 \\
4.2 \\
6.4 \\
5.9\end{array}$ & $\begin{array}{l}19.8 \\
18.3 \\
14.9\end{array}$ & $\begin{array}{r}7.2 \\
11.0 \\
10.6 \\
11.3 \\
9.8\end{array}$ & $\begin{array}{l}4.9 \\
4.7 \\
4.1 \\
1.4 \\
5.9 \\
6.4\end{array}$ & $\begin{array}{l}10.5 \\
21.0 \\
20.5 \\
19.7 \\
17.2 \\
16.3\end{array}$ & $\begin{array}{r}7.6 \\
13.0 \\
14.4 \\
12.2 \\
12.1 \\
10.8\end{array}$ & $\begin{array}{l}4.0 \\
5.5 \\
7.7 \\
6.4 \\
6.1 \\
5.4\end{array}$ \\
\hline Average & 11.4 & 7.7 & 4.7 & 17.1 & 10.1 & 5.1 & 17.5 & 11.7 & 5.8 \\
\hline
\end{tabular}

Table 3. Daily DO consumption $(H)$, daily $\mathrm{DO}-\mathrm{O}_{2}$ exchange (E) and daily DO production $(P)$ with their hourly maximum, average and minimum values obtained from BLOC (4).

\begin{tabular}{|c|c|c|c|c|c|c|c|c|c|}
\hline \multirow{2}{*}{ Date } & \multicolumn{3}{|c|}{ PF. A } & \multicolumn{3}{|c|}{ PF. B } & \multicolumn{3}{|c|}{$\mathrm{CR}$} \\
\hline & $H$ & $E$ & $P$ & $H$ & $E$ & $P$ & $H$ & $E$ & $P$ \\
\hline $\begin{array}{l}7 / 22 \\
8 / 21 \\
9 / 24\end{array}$ & $\begin{array}{l}23.1 \\
15.4 \\
11.9\end{array}$ & $\begin{array}{r}+7.20 \\
+7.10 \\
+8.70\end{array}$ & $\begin{array}{r}17.0 \\
8.3 \\
3.7\end{array}$ & $\begin{array}{r}20.2 \\
14.5 \\
9.5\end{array}$ & $\begin{array}{r}+5.00 \\
+2.10 \\
+0.40\end{array}$ & $\begin{array}{r}16.0 \\
11.0 \\
8.6\end{array}$ & $\begin{array}{l}24.0 \\
23.9 \\
22.5\end{array}$ & $\begin{array}{l}+2.90 \\
\$ 0.60 \\
\$ 4.90\end{array}$ & $\begin{array}{l}21.0 \\
24.6 \\
18.6\end{array}$ \\
\hline Average & 16.8 & +7.70 & 9.7 & 14.7 & +2.50 & 11.9 & 23.5 & $\mathrm{f} 2.80$ & 21.4 \\
\hline \multirow{2}{*}{ Date } & \multicolumn{3}{|c|}{ PF. A } & \multicolumn{3}{|c|}{ PF. B } & \multicolumn{3}{|c|}{$\mathrm{CR}$} \\
\hline & Max. & Ave. & Min. & Max. & Ave. & Min. & Max. & Ave. & Min. \\
\hline $\begin{array}{l}7 / 22 \\
8 / 21 \\
9 / 24\end{array}$ & $\begin{array}{r}18.6 \\
7.9 \\
.\end{array}$ & $\begin{array}{l}6.20 \\
6.20 \\
6.90\end{array}$ & $\begin{array}{l}2.90 \\
4.80 \\
6.00\end{array}$ & $\begin{array}{r}12.2 \\
11.8 \\
8.8\end{array}$ & $\begin{array}{l}6.50 \\
7.50 \\
7.20\end{array}$ & $\begin{array}{l}2.70 \\
4.90 \\
5.60\end{array}$ & $\begin{array}{l}11.7 \\
13.9 \\
30.3\end{array}$ & $\begin{array}{l}7.50 \\
8.40 \\
6.10\end{array}$ & $\begin{array}{l}3.60 \\
3.30 \\
2.30\end{array}$ \\
\hline Average & 9.3 & 6.40 & 4.60 & 10.9 & 7.10 & 4.40 & 32.0 & 7.30 & 3.10 \\
\hline
\end{tabular}

\section{(d) Relationships between DO and other factors}

In Fig. 10, the relationships of DO to intensity of solar radiation and water temperature are illustrated using the data from the lysimeter and paddy fields. 
Table 4. Daily DO consumption (H), daily $\mathrm{DO}-\mathrm{O}_{2}$ exchange (E) and daily $\mathrm{DO}$ production (P) with their hourly maximum, average and minimum values obtained from BLOC (5).

\begin{tabular}{|c|c|c|c|c|c|c|c|c|c|c|c|}
\hline \multirow{2}{*}{ Date } & \multicolumn{4}{|c|}{ PF. 1} & \multicolumn{3}{|c|}{ PF. 2} & \multicolumn{4}{|c|}{$\mathrm{CR}$} \\
\hline & & H & $\mathbf{E}$ & $\mathbf{P}$ & $H$ & E & $\mathbf{P}$ & | & $H$ & $E$ & $\mathbf{P}$ \\
\hline $\begin{array}{l}7 / 23 \\
8 / 22 \\
9 / 24\end{array}$ & $\begin{array}{l}24 \\
28 \\
24\end{array}$ & $\begin{array}{l}4.3 \\
8.9 \\
4.4\end{array}$ & $\begin{array}{l}+3.00 \\
-1.80\end{array}$ & $\begin{array}{r}25.7 \\
31.0\end{array}$ & $\begin{array}{c}22.0 \\
30.2 \\
18.7\end{array}$ & $\begin{array}{l}-1.30 \\
+2.70\end{array}$ & $\begin{array}{l}23.3 \\
27.6\end{array}$ & $i$ & $\begin{array}{l}26.0 \\
36.5 \\
37.7\end{array}$ & $\begin{array}{l}-2.5 \\
+5.6 \\
+22.4\end{array}$ & $\begin{array}{l}28.6 \\
32.9\end{array}$ \\
\hline Average & & 5.9 & $+7.00+2.70$ & 24.717 .4 & $\left.23.6\right|^{\circ}$ & $+2.60+1.30$ & 16.322 .4 & & 33.4 & +8.51 & 15.525 .7 \\
\hline \multirow{2}{*}{ Date } & \multicolumn{4}{|c|}{ PF. 1} & \multicolumn{3}{|c|}{ PF. 2} & \multicolumn{4}{|c|}{$\mathrm{CR}$} \\
\hline & $\mathrm{M}$ a $\mathrm{x}$ & $\mathrm{x}$. & Ave. & Min. & Max. & Ave. & Min. & & Max. & Ave. & Min. \\
\hline $\begin{array}{l}7 / 23 \\
8 / 22 \\
9 / 24\end{array}$ & & $\begin{array}{l}16.2 \\
17.3 \\
13.7\end{array}$ & $\begin{array}{l}7.10 \\
8.70 \\
7.40\end{array}$ & $\begin{array}{l}1.7 \% \\
3.2 \\
4.0 \\
4.0\end{array}$ & $\begin{array}{l}16.2 \\
16.1 \\
13.2\end{array}$ & $\begin{array}{l}8.70 \\
6.90 \\
8.50\end{array}$ & $\begin{array}{l}4.7 \\
1.4 \\
5.1\end{array}$ & & $\begin{array}{r}15.5 \\
14.9 \\
8.2\end{array}$ & $\begin{array}{l}9.0- \\
6.5 \\
\breve{4} .3\end{array}$ & $\begin{array}{l}3.6 \\
0: 8 \\
2.1\end{array}$ \\
\hline Average & & 15.7 & 7.70 & 3.0 & 15.2 & 8.0 & 3.7 & & 12.9 & 6.6 & 2.2 \\
\hline
\end{tabular}

There were observed certain time lags between the increases in DO in water and in the intensity of solar radiation. However, the raise of water temperature happened concurrently with DO increase. The direct effect of raising temperature was to reduce the DO in water as shown in the curve of saturated DO in which the high temperature in day-time resulted in small oxygen concentration. But high water temperature, accompanied with solar radiation, affected directly the growth and metabolic processes of the aquatic organisms. As a matter of fact, the DO values changed in a proportional trend with temperature and intensity of solar radiation.

Table 5 shows the variation of average DO and the factors such as average air temperature, intensity of solar radiation, average height and tiller number of rice plants on each in 6 days of measurement in Ly, of BLOC(3).

Table 5. Relationships between $\mathrm{DO}$ and other in situ factors: data in $\mathrm{Ly}_{6}$ of rice season in 1974.

\begin{tabular}{|c|c|c|c|c|c|}
\hline Date & $\begin{array}{l}\text { Ave. Ai: } \\
\text { Tepaper iture } \\
\left({ }^{\circ} \mathrm{C}\right)\end{array}$ & $\begin{array}{c}\text { Solar } \\
\text { Radiation } \\
\text { (cal } / \mathrm{cm}^{2} / \text { day) }\end{array}$ & $\begin{array}{l}\text { Average } \\
\text { 'DO' } \\
\text { (ppm) }\end{array}$ & $\begin{array}{l}\text { Plant } \\
\text { Height } \\
\text { (cm) }\end{array}$ & $\begin{array}{c}\text { Tiller } \\
\text { Number } \\
\text { (number) }\end{array}$ \\
\hline $7 / 19$ & 27.9 & - & & 37.5 & 12 \\
\hline $8 / 13$ & 28.0 & 445.0 & $\begin{array}{r}7 \cdot \hat{0} \\
13: 0\end{array}$ & 51.0 & $\begin{array}{l}19 \\
20\end{array}$ \\
\hline $\begin{array}{r}9 / 19 \\
10 / 05\end{array}$ & $\begin{array}{l}19.024 .7 \\
18.8\end{array}$ & $\begin{array}{l}450.0314 .0 \\
251.0\end{array}$ & $\begin{array}{l}12.212 .1 \\
10.8\end{array}$ & $\begin{array}{l}101.589 .0 \\
103.0\end{array}$ & $\begin{array}{l}2020 \\
20\end{array}$ \\
\hline
\end{tabular}

In Ly,, after rice plants were transplanted, Pithophora was still present in small density and this related to small DO in July. In the middle of August, 


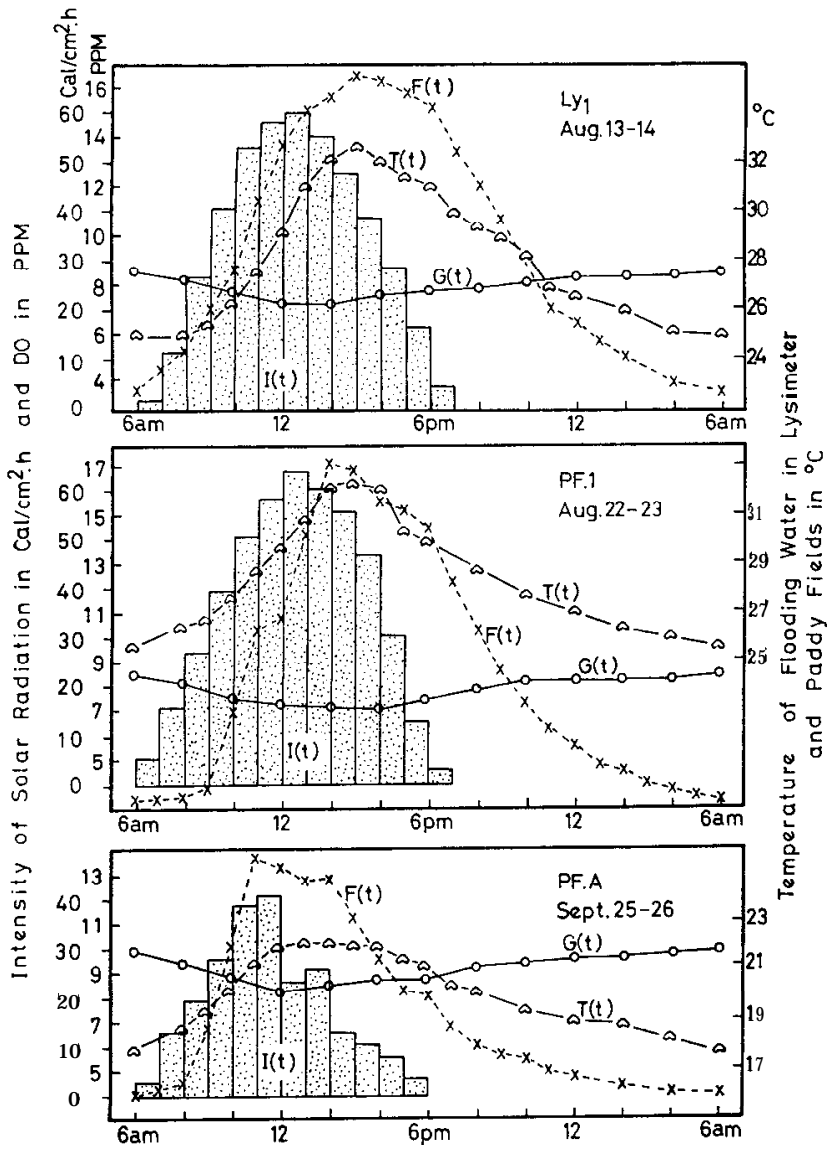

Fig. 10. Some examples about the relationships among the DO diurnal curve $F(t)$, saturated DO $G(t)$, water temperature $T(t)$ and intensity of solar radiation $I(t)$.

when both temperature and sun-light intensity attained the maximum levels, DO in water was also the largest. On the subsequent stages of the rice planting season, all the 3 values decreased gradually while Pithophora and other aquatic plants became prostrate and degenerated.

Furthermore, the shading effect of rice plants also took part in changing DO value in water. From the tillering and elongation stages, both width and height of rice plants increased progressively, these obstructed the sun-light and temperature to reach upon the water body, diminished the metabolic activities directly, and reduced the DO in water indirectly,

\section{ACKNOWLEDGEMENTS}

We desire to offer our true thankfulness to Dr. Prof. Shinya Ishio, Dr. Prof. Kohei Tanaka, Dr. Ass. Prof. Yushiro Motoda, the Assistants Akira Tanaka 
and Yoshisuke Nakano, Mr. Tamotsu Funakoshi as well as other members in the Laboratory of Irrigation Engineering, from whom we had received many advices and helps.

\section{REFERENCES}

Bartsch, A. F. 1961 Algae as a source of oxygen in waste treatment. J. W PCF., 33: 239-249 Carpenter, J.H. 1966 New measurements of oxygen solubility in pure and natural waler. Limnol. 0 ceanogr., 11: 264-277

Darbg, R. E. 1962 Midges associated with California rice fields, with special reference to their ecology (Diptera : Chironomidae) Hilgardia, 32: I-206

Downing, A. L. and G. A. Truesdale 1955 Some factors affecting the rate of solution of oxygen in water. J. Appl. Chem., 5: 570-581

Kanwisher, J. 1963 On the exchanges of gases between the atmosphere and the sea. Deep Sea Res., 10 : 195-207

Liss, P. S. 1973 Processes of gas exchange across an air-water interface. Deep Sea Res., $20: 221-238$

Montgomery, H. A. C., N. S. Thorn and A. Cockburn 1964 Determination of dissolved oxygen by the Winkler method and the solubility of oxygen in pure water and sea water. J. Appl, Chem., 14: 280-296

Odum, H. T. 1956 Primary production in flowing waters. Limnol. O ceanogr., 1: 102-117

Ryther, J. H. 1956 Photosynthesis in the ocean as a function of light intensity. Limnol. O ceanogr., 1: $61-70$

Toyota, M. 1972 Study on the effect of low content oxygen water on the rice growth and the simple method for DO measurement (in Japanese). Wat. Purif. Liq. Wast. Treatm., 13: 25-32

Truesdale, G. A., A. L. Downing and G. F. Lowden 3955 The solubility of oxygen in pure water and sea-water. J. Appl. Chem., 5: 53-62

Welch, H.E. 1968 Use of modified diurnal curves for the measurement of metabolism in standing water, Limnol. O ceanogr., 19: 65-73 